\author{
Jacek UCHMAN, PhD, Professor of Wroclaw University of Economics \\ Faculty of Economics and Finance, Wroclaw University of Economics \\ e-mail: jacek.uchman@ue.wroc.pl \\ ORCID: 0000-0001-9852-5320
}

DOI: $10.15290 /$ oes.2020.04.102.01

\title{
THE TAXATION OF CONTROLLED FOREIGN CORPORATIONS' INCOME AND ITS SELECTED CONSEQUENCES ${ }^{1}$
}

\begin{abstract}
Summary
Purpose - The aim of this study is an evaluation of the possibility of maximising budget income due to the tax regulations concerning controlled foreign corporations. The objective is to gain an understanding of these regulations for shaping the profitability of the investments performed abroad.

Research method - The study approach uses a method of analysis of financial consequences resulting from the regulations existing in this area and the simplified analysis of profitability allowing for the tax factor. In the study companies and corporate income tax were taken into consideration.

Results - It has been proven that taxation without deferral influences the tax amount and the rate of return of a taxpayer being the shareholder of these corporations. The implication of certain mechanisms in foreign controlled corporations' regulation has been estimated. A relatively small scale of the investments coming from Polish residents has been shown. The phenomenon may result in comparatively minor income coming from these regulations.

Originality / value / implications / recommendations - The author has shown economic conditionings and the consequences of the analysed regulations. In Polish sources concerning this issue, legal challenges had previously dominated. In this study, the estimates of shaping profitability post taxation have been performed on the basis of the available data. The analysed mechanism is one of the several regulations concerning the regulation of the taxation of companies acting on an international scale. Due to their abundance, the remaining solutions have been used as the reference for the examined mechanism.
\end{abstract}

Keywords: tax deferral, controlled foreign companies, profitability of investment

JEL Classification: $\mathrm{H} 25, \mathrm{H} 26, \mathrm{~F} 21$

${ }^{1}$ Article received on 01 April 2020, accepted on 26 June 2020. 


\section{Introduction}

The limitation of paying taxes in the settlements of companies trading on the international scale is the operating area of tax planning. Tax regulations relating to controlled foreign corporations (CFCs) in particular countries are aimed chiefly at minimising tax losses of the public sphere that occur as the result of the activity of economic entities in international settlements.

The regulations concerning CFCs were introduced into corporate tax law (CIT) in 2015. They also occur in personal income tax law (PIT), however the domain concerning physical individuals extends beyond the focus of this research paper. The fundamental economic aim of the regulations is to tighten the collection of the corporate tax law and force Polish taxpayers (residents) to pay earlier corporate taxes on the incomes achieved by the entities related by capital that do not have their headquarters in Poland, instead of endlessly postponing it abroad. Hence it involves the residents investing abroad and is aimed to speed up the taxations of their incomes earned outside Poland. These regulations to a certain degree resemble the solutions found in other countries [Garfunkel, 2010, pp. 54-70]. They concern the investments performed abroad and the transfer of incomes realised by Polish taxpayers. The corporate income tax [Act, 1992] lists various organisational and legal forms of the entities creating CFCs, however in this paper the subject of the analysis will be narrowed down to capital companies. The fundamental problems regarding the regulations on CFCs may be divided into two simple groups. The first group includes the challenges concerning economic and legal criteria of how to precisely define this group of entities and properly specify the minimum scale of involvement of a taxpayer that is a resident in the country being the donor of capital for CFCs. The first group decides upon the scope of the regulations functioning and, as a consequence, is also of significant importance in fiscal terms. The second type of issue which constitute the main aim of the analysis includes the definition and construction of the tax base and the assumptions of the tax itself. In other words, the goal of the analysis is to confirm whether the selected construction elements in the taxation influence the profitability of corporations and the amount of the tax paid by them. Therefore, there emerge the problems related to gross and net profitability of CFCs and the increase of tax as the effect of the lack of tax deferral. An attempt was made to evaluate whether this form of taxation to a considerable degree modifies the profitability of the entities and thus also what is its fiscal efficiency. Additionally, the scale of the investment of Polish residents abroad in relation to foreign investments in Poland was outlined. CFCs were reduced here to public limited liability companies although also the personal income tax law implies that they may adopt various forms. Dividends, which constitute the most important form of income transfer to the home country, are legally attached to capital companies. In the paper it is assumed that dividends are paid to legal persons. The figures regarding the transfer of incomes by economic operators on an international scale are limited, therefore the conclusions ought to be drawn carefully. 


\section{The subjective range of CFCs and the specificity of their income taxation}

Controlled foreign corporations are either companies or other organisational and legal forms operating outside the territory of Poland. There are three basic criteria that enable considering a foreign corporations as a controlled one. The first two criteria are of territorial and tax nature. The CFC has its headquarters in a country that is listed among the countries using unfair tax competition or (the second criterion) in a country with which Poland has not signed the bilateral tax agreement on the avoidance of double taxation or with which the European Union (EU) has not signed the international agreement on the exchange of information. The third criterion is characterised by three quantitative factors: The CFC must be the entities where the Polish taxpayer has a minimum of $50 \%$ stock (shares) holdings or voting rights; at least $33 \%$ of their incomes constitute the so-called passive incomes (dividends, interest, the disposal of stocks/shares, etc.) [Act, 1992, art.24a]. Furthermore, the territory must be characterised by lower rates of income tax ${ }^{2}$. Initially, such regulations were not addressed at the entities functioning on a small scale ${ }^{3}$, but since 2018 the limit of turnover has not been considered [Dmowski, 2019, pp. 1920; Kuźniacki, 2017].

In the option with the dividend paid out the tax may be calculated as follows:

The sum of Polish corporate income tax on the income of controlled foreign corporation (CFC):

$$
\mathrm{CFC}=\mathrm{T}_{\mathrm{CP}}\left(\mathrm{D}_{\mathrm{ZJK}}-\mathrm{DIV}-\mathrm{CG}\right) \text {, }
$$

where: $\mathrm{T}_{\mathrm{CP}}$ - the corporate income tax rate in Poland, $\mathrm{D}_{\mathrm{ZJK}}$ - the income of CFC in the part accruing to a Polish taxpayer, DIV- the value of dividends paid by CFC for a certain year and included in the taxpayer's tax base, CG - the incomes from the profitable sale of CFC shares by a taxpayer which are included in their tax base. ${ }^{4}$

If the sum in the brackets is greater than zero, there occurs tax without deferral paid by a Polish resident. CFC tax paid abroad in this formula is calculated on the basis of the income determined in accordance with the act on the corporate income act. CFC losses are not deducted from the income of the Polish taxpayer. The deductibility of the dividends paid and of capital profits serves the reduction of

\footnotetext{
2 The rates of the income tax levied on the incomes of corporations in the country where CFC headquarters are located ought to be lowered at least by one half in comparison with the basic rate of the corporate income tax in Poland. Theoretically, this criterion may be calculated on the basis of the provisions of art. 24a act 3 item $3 \mathrm{c}$. Practical calculation may be more difficult owing to the multitude of solutions in income taxes in particular countries.

${ }^{3}$ The limit of turnover amounted to $€ 250,000$. However, in 2018 the limit was liquidated. Aside from the emerging motive of adjustment processes to model solutions (ATAD directive), this may indicate great expectations of fiscal authorities as regards incomes in this area.

${ }_{4}$ Own elaboration based on: [Act, 1992, art. 24a act 4 and 6]. In practice, it is possible to calculate income tax on legal persons from the entire income of CFC and deduct the paid foreign VAT accruing on a foreign shareholder.
} 
double taxation. In general, the high rate at which dividends are paid by a particular CFC brings into question the reasonableness of using these regulations in relation to them. If the conditions of art. 22b of the corporate income tax ${ }^{5}$ [Act,1992, art. 22b] are complied with, it is possible to calculate the tax paid in the CFC home country, i.e. the corporate income tax in Poland will be as follows:

$$
\mathrm{T}_{\mathrm{CP}}\left(\mathrm{D}_{\mathrm{ZJK}}-\mathrm{DIV}-\mathrm{CG}\right)-\left[\mathrm{T}_{\mathrm{CZ}}\left(\mathrm{D}_{\mathrm{ZJK}}: \mathrm{U}_{\mathrm{p}}\right)\right] \mathrm{U}_{\mathrm{P}},
$$

where $\mathrm{U}_{\mathrm{p}}$ - the share of income accruing to Polish taxpayer in the entire CFC income in the home country of $\mathrm{CFC}$; $\mathrm{T}_{\mathrm{CZ}}$ - the corporate income tax rate in the country of the $\mathrm{CFC}$ headquarters.

Generally speaking, the profitability of this mechanism for the resident's country (the country where the headquarters of the shareholder or stockholder are located) depends on the difference between the tax rates of incomes between the home country of the Polish taxpayer and the country of the CFC headquarters i.e. $\mathrm{T}_{\mathrm{CP}}>\mathrm{T}_{\mathrm{CZ}}$. Furthermore, one of the criteria classifying the entities as the controlled ones implies that the CFC may be perceived as such when it operates in a country where the rates of taxation meet the following condition: $\mathrm{T}_{\mathrm{CZ}} \mathrm{D}_{\mathrm{ZJK}}<\mathrm{T}_{\mathrm{CP}} \mathrm{D}_{\mathrm{ZJK}}-\mathrm{T}_{\mathrm{CZ}} \mathrm{D}_{\mathrm{ZJK}}{ }^{6}$ On the one hand, the adoption of this criterion may narrow down the number of entities which can be classified as CFC, however on the other hand, it demonstrates that there can be considerable benefits of the home country (in this case: Poland) resulting from the difference of tax rates. Naturally, $\mathrm{T}_{\mathrm{CZ}}$ does not necessarily mean a flat rate for particular types of passive incomes.

The benefits for the country of the seat (residence) of the taxpayer (Poland) may be subject to modifications by the mechanism of dividend taxation. In the case of dividend payment, it is difficult to precisely define the total tax benefits for the home country because it is necessary to consider the scale of payments (the indicator of dividend distribution) and the mechanism of the taxation of dividends transferred to the home country which may be different for corporate income tax and the personal income tax. Dividends may be described as passive income, but on the international scale they are mainly the basic form of transferring money between the entities related by shares?

If a Polish taxpayer who receives dividends is subject to personal income tax, it is impossible to avoid the dividend tax. The situation is different when dividends are

\footnotetext{
5 The allowance may be made if there is legal basis to obtain information by fiscal apparatus that results from the bilateral agreement on the avoidance of double taxation or any other agreement signed by Poland.

${ }^{6}$ It results from: [Act, 1992, art. 24 act 3 item 3c]. As regards foreign incomes there is mentioned "actually paid income tax" which includes various deductions and reliefs. Therefore, the theoretical calculation of the nominal upper rate of CFC income tax from the disparity included in the act will not have a universal character because it will not take into account all the elements that shape the effective rates of tax which can vary in the income taxes of particular countries.

${ }^{7}$ The data from NBP is such even though it does not comprise the transfers made at the level of costs.
} 
received by a legal person that needs to pay the corporate income tax. Taxation is mitigated by the double taxation avoidance methods. The double taxation avoidance methods on the international scale concern chiefly the incomes paid in the form of dividends [Uchman, 2002, p. 218]. There are also special regulations regarding the transfer of dividends between the taxpayers having their headquarters in the European Union.

\section{The profitability of the investments of Polish residents and the consequences of their taxation via CFC}

As already mentioned, the definition of the CFC entity has fundamental importance for the scope of the regulation. The type of an entity, the location from the perspective of tax competitiveness, the types of obtained incomes specify the qualification to this category of entities. The second important factor is the taxation manner, i.e. the construction of the tax base and the date at which the tax is taken. The tax collection date may affect the profitability of the investment as well as the tax amount, but the effects of it may be estimated to a limited extent.

The profit of a CFC being the limited company may be transferred abroad to the home country of the shareholder (or any other country) in the form of dividends or it may remain in a corporation and be reinvested so that it can (as any other investment) generate a certain rate of return. To calculate what is the net rate of return that a shareholder expects, it is important to know whether the tax is deferred or not.

In the situation where CFC profit is reinvested in its home country (where the investment was made) over a few years' period in accordance with the same rate of return and there is tax deferral, the rate of return (profitability) from single investment may be presented as follows [Bizer, 1992, p. 598; Rust, pp. 492-493]:

$$
\left[\left(1+r_{b}\right)^{n_{-}}-T_{C P}\left[\left(1+r_{b}\right)^{n}-1\right],\right.
$$

where: $r_{b}$ - the rate of return from the investment before tax, $T_{C P}$ the rate of income tax from legal persons, $\mathrm{n}$-the number of years.

However, if the taxation of CFC incomes is not deferred, we can write the rate of return after tax in the following way:

$$
\left(\left[1+r_{b}\left(1-T_{C P}\right)\right]^{\mathrm{n}}\right) .
$$

For both variants it is possible to calculate the rates of return after tax having various levels of $r_{b}$ and different years of reinvesting profits (table 1). 
TABLE 1

The profitability of the investment after $\mathbf{n}$ years when payment is immediate or deferred, with the tax rate amounting to $19 \%$ and various rates of return*

\begin{tabular}{|c|c|c|c|c|}
\hline $\begin{array}{l}\text { The rate of return from the investment } \\
\qquad\left(\mathrm{r}_{\mathrm{b}}\right)\end{array}$ & $3 \%$ & $5 \%$ & $7 \%$ & $9 \%$ \\
\hline \multicolumn{5}{|l|}{$\begin{array}{l}\text { The value of } 1 \text { PLN in the situation } \\
\text { of the reinvestment of profit and using } \\
\text { CIT taxation without deferral after the: }\end{array}$} \\
\hline $1^{\text {st }}$ year & 1.02 & 1.04 & 1.06 & 1.07 \\
\hline $5^{\text {th }}$ year & 1.13 & 1.22 & 1.33 & 1.44 \\
\hline $10^{\text {th }}$ year & 1.28 & 1.51 & 1.78 & 2.11 \\
\hline $15^{\text {th }}$ year & 1.45 & 1.87 & 2.43 & 3.14 \\
\hline \multicolumn{5}{|l|}{$\begin{array}{l}\text { The value of } 1 \text { PLN in the situation of } \\
\text { CIT taxation without deferral after the: }\end{array}$} \\
\hline $1^{\text {st }}$ year & 1.02 & 1.04 & 1.06 & 1.07 \\
\hline $5^{\text {th }}$ year & 1.13 & 1.22 & 1.32 & 1.42 \\
\hline $10^{\text {th }}$ year & 1.27 & 1.49 & 1.74 & 2.02 \\
\hline $15^{\text {th }}$ year & 1.43 & 1.81 & 2.29 & 2.87 \\
\hline
\end{tabular}

* Assumptions were made concerning the non-changeability of CIT rate (19\%) and the rates of return for particular years.

Source: own calculations.

The calculations presented in table 1 indicate the benefits of tax deferral. For a taxpayer such benefits increase in correlation with the years of deferral and the value of the rates of return before tax. International elaborations indicate that the average rate of return from direct foreign investment in OECD countries (calculated as: (dividends + reinvested profits + incomes from debt instruments): the investment volume) for foreign investments made by entities from these countries in the years $2012-2016$ oscillated from $7 \%$ to $4 \%$, however this tendency is decreasing [Foreign Direct Investment in..., 2017, pp. 8-12] ${ }^{8}$. In contrast, the rates of return from direct foreign investments in EU-28 countries for 2016 and 2017 amounted to 3.7\% and $4.5 \%$ respectively [Foreign Direct Investment..., 2019]. These rates are net values because the incomes from stocks are incomes after tax, while the qualification of their interest is not so unambiguous 9 .

Meanwhile, the profitability of direct foreign investment made by Polish residents abroad between the years 2012-2018 may be calculated based on the data from NBP. It oscillates from $1.5 \%$ to $8.8 \%$ in particular years. Similarly, to the elaborations for the OECD and EU-28 countries, the income which constitutes the

8 There was large branch variation of the rates of return.

${ }^{9}$ It is necessary to consider at least taxation in the country of the investment as well as to take into account the frequently observed in income taxes the effect of a tax shield that neutralizes this taxation. 
basis for these calculations includes dividends, reinvested profits and interest. It does not include the payments made at the level of costs. On the other hand, reinvested profits and dividends are after corporation tax. Hence it is difficult to precisely determine the average gross and net profitability of Polish direct foreign investments, while it has considerable importance for the estimation of the change in the taxation burden of the taxpayer related to these regulations. If this profitability is a net value, it is possible to gross it using the upper tax rate for the taxation of CFC, i.e. approx. 9\%. In this situation, these rates will oscillate from $1.98 \%$ to $9.7 \%{ }^{10}$. This will only insignificantly change the level of profitability. In order to consider this changeability of the rates of return, table 1 presents the calculations for their different levels.

For the period of 15 years and the highest analysed gross rate of return $(9 \%)$, the percentage change between the income after deferred tax and the income after tax without deferral amounts to approx. $9 \%$ This is the highest percentage range for the data analysed in the table. In all of the other cases the percentage changes in the rates of return are even smaller as the consequence of such change of the taxation manner. The elimination of deferred tax provides moderate benefits for the budget of the home country of the corporation being CFC shareholder. However, the actual reason of eliminating tax deferral may be the concern that these incomes may be entirely lost, i.e. there is fear that the deferral of the transfer to the taxpayer's home country may last almost endlessly. Furthermore, these calculations do not include all the possibilities that taxpayers have. Money may be transferred at the level of CFC costs and finally the taxpayer that is determined not to pay tax, may finally change their residence for tax purposes.

It should also be noted that the profitability of direct foreign investments only to a limited extent may be compared and used to estimate the profitability of CFC the incomes of which are passive to a large degree.

Fiscal efficiency of the analysed solutions depends on the number and size of the taxpayers covered by these regulations. Polish regulations in this respect do not differ from the solutions used in other developed countries. From the budget perspective, fiscal efficiency is also dependent on the scale of Polish direct foreign investments made in the form subject to that taxation. It is worth analysing the basic available data in this field concerning Poland. Chart 1 presents the value of direct investments of Polish residents abroad and of direct foreign investments in Poland. The difference between these two values also shows (not directly) the potential difference between tax revenues from both locations of the investments ${ }^{11}$.

\footnotetext{
${ }^{10}$ Calculated as: the net rate of return: (1-0.09).

${ }^{11}$ It also depends on other factors, among others, on whether the proportions will be respected during the transfer abroad and the transfer to Poland.
} 
CHART 1

The assets and liabilities connected with foreign investments in mln PLN

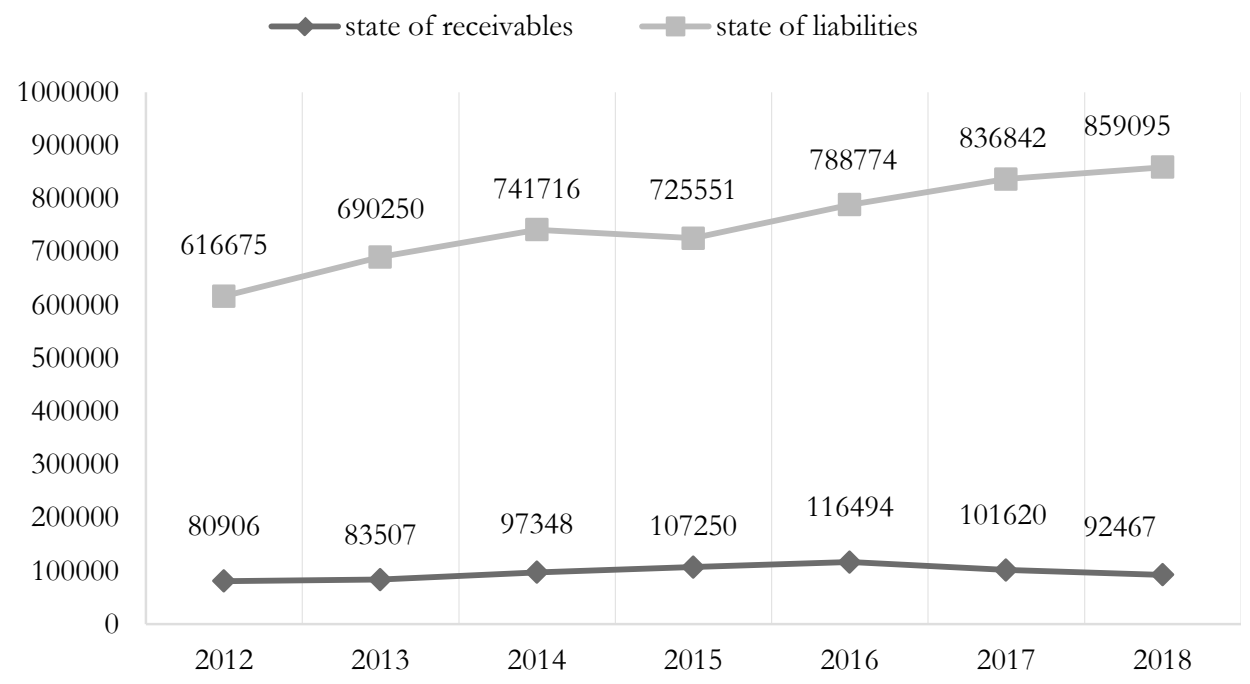

Source: own elaboration based on: [Zagraniczne inwestycje beapośrednie ...; Polskie inwestycje beapośrednie...].

The state of active debts from Polish direct investments decreased in the years 2017-2018 as the result of various factors, also due to the change in residence of certain Polish taxpayers. The relationship between direct foreign investments of Polish residents and direct foreign investments of residents in Poland was rather low in this entire period.

The profitability of Polish direct investments abroad in the years 2012-2018 was subject to considerable fluctuations which were greater than those observed as regards the profitability of foreign investments in Poland (table 1). As regards 2013 and 2015 one may reflect on the financial meaning of such investments (table 1 includes the analysis of only the aggregated data for all branches). However, the comparison of the rates of return (the indicators of profitability) does not necessarily need to provide a complete image of the financial situation of a corporation.

When compared with the incomes of foreign residents in Poland, the incomes of Polish residents abroad are not high (table 2). The incomes of taxpayers are the source of budget revenues, which clearly indicates that direct foreign investments in Poland create potentially larger possibilities of obtaining budget revenues than direct investments of Polish residents abroad. However, in order to draw more precise conclusions from this data it is necessary to have more useful synthetic summaries (data from the Ministry of Finance) concerning the amount of the tax paid in the same groups. 
TABLE 2

The incomes and profitability of Polish residents abroad and of foreign residents in Poland from direct foreign investments in the years 2012-2018 (incomes in mln PLN)*

\begin{tabular}{|l|c|c|c|c|c|c|c|}
\hline \multicolumn{1}{|c|}{ Years } & $\mathbf{2 0 1 2}$ & $\mathbf{2 0 1 3}$ & $\mathbf{2 0 1 4}$ & $\mathbf{2 0 1 5}$ & $\mathbf{2 0 1 6}$ & $\mathbf{2 0 1 7}$ & $\mathbf{2 0 1 8}$ \\
\hline $\begin{array}{l}\text { The incomes of Polish } \\
\text { direct investments } \\
\text { abroad }\end{array}$ & 4330.1 & 1284.4 & 5036.6 & 3071.9 & 3961.6 & 8643.0 & 8182.0 \\
\hline $\begin{array}{l}\text { The profitability of } \\
\text { Polish investments } \\
\text { abroad (in \%) }\end{array}$ & 5.3 & 1.5 & 5.1 & 2.8 & 3.4 & 8.5 & 8.8 \\
\hline $\begin{array}{l}\text { The incomes of foreign } \\
\text { direct investments } \\
\text { in Poland }\end{array}$ & 52030.6 & 58234.7 & 64127.6 & 67506.9 & 81949.6 & 81219.8 & 86502.5 \\
\hline $\begin{array}{l}\text { The profitability of } \\
\text { foreign investments } \\
\text { in Poland (in \%) }\end{array}$ & 8.4 & 8.4 & 8.6 & 9.3 & 10.4 & 9.7 & 10 \\
\hline $\begin{array}{l}\text { The relation between } \\
\text { direct foreign invest- } \\
\text { ments abroad and direct } \\
\text { foreign investments in } \\
\text { Poland (\%) }\end{array}$ & 13.1 & 12.1 & 13.1 & 14.8 & 14.8 & 12.1 & 10.8 \\
\hline
\end{tabular}

* The profitability of the investments was calculated in accordance with the methodology of the OECD, i.e. the incomes: the value of the invested capital.

Source: own calculations based: [Zagraniczne inwestycje beapośrednie ...; Polskie inwestycje beazpośrednie...].

TABLE 3

\section{Selected factors that potentially shape fiscal effectiveness ${ }^{12}$ of CFC regulations*}

\begin{tabular}{|l|l|l|}
\hline \multicolumn{1}{|c|}{ Factors } & The reduction of fiscal benefits & \multicolumn{1}{c|}{$\begin{array}{c}\text { The increase of fiscal } \\
\text { benefits }\end{array}$} \\
\hline $\begin{array}{l}\text { The relation between } \\
\text { the rates in the } \\
\text { country of } \\
\text { headquarters and the } \\
\begin{array}{l}\text { country of the invest- } \\
\text { ment }(\mathrm{CFC} \text { country) }\end{array}\end{array}$ & $\begin{array}{l}\text { Benefits are decreasing } \\
\text { simultaneously with the increase } \\
\text { of } \mathrm{T}_{\mathrm{CZ}} \text { in relation to } \mathrm{T}_{\mathrm{CP}} \text {. These } \\
\text { benefits may be completely } \\
\text { eliminated because } 2 \mathrm{~T}_{\mathrm{CZ}}>\mathrm{T}_{\mathrm{CP}}\end{array}$ & $\begin{array}{l}\text { Benefits are increasing the } \\
\text { more } \mathrm{T}_{\mathrm{CZ}}<\mathrm{T}_{\mathrm{CP}}\end{array}$ \\
\hline
\end{tabular}

\footnotetext{
${ }^{12}$ Here it is understood as the increase in the income from the corporate tax.
} 


\begin{tabular}{|l|l|l|}
\hline \multicolumn{1}{|c|}{ Factors } & \multicolumn{1}{|c|}{ The reduction of fiscal benefits } & \multicolumn{1}{|c|}{$\begin{array}{c}\text { The increase of fiscal } \\
\text { benefits }\end{array}$} \\
\hline The accrual principle & $\begin{array}{l}\text { The functioning of this principle } \\
\text { does not have impact on } \\
\text { reducing the benefits of fiscal } \\
\text { authorities }\end{array}$ & $\begin{array}{l}\text { The tax is increasing along } \\
\text { with the number of years } \\
\text { and the rate of investment } \\
\text { profitability in comparison } \\
\text { with taxation by means of } \\
\text { cash method }\end{array}$ \\
\hline $\begin{array}{l}\text { Other mechanisms } \\
\text { and instruments of tax } \\
\text { planning }\end{array}$ & $\begin{array}{l}\text { The application of the forms of } \\
\text { transferring funds to the home } \\
\text { country at the cost level, } \\
\text { transactions between groups } \\
\text { [Majdowski,2017, p. 18] }\end{array}$ & $\begin{array}{l}\text { Statutory regulations } \\
\text { hindering the usage of } \\
\text { transfer prices and thin } \\
\text { capitalization }\end{array}$ \\
\hline
\end{tabular}

* There were selected structural elements that shape the tax base and tax rates. There were omitted main legislative and economic criteria which qualify an entity as $\mathrm{CFC}$. $\mathrm{T}_{\mathrm{CZ}}, \mathrm{T}_{\mathrm{CP}}-$ as before.

Source: own elaboration based on: [Act, 1992].

\section{Conclusions}

The regulations concerning CFCs are among the regulations concerning the entities operating at the international scale within the provisions of the act on the corporate income tax. In contrast to the majority of them, they regard the transfer of incomes made from abroad by residents to their home country. Another distinguishing feature of these regulations is the acceleration of tax will not need to wait until those incomes will reach the home country of the taxpayer that is the CFC shareholder. In this way account shall be taken of diverse and extended opportunities of investing abroad by residents.

Contrary to more developed countries, Poland is the recipient of net capital and these tax solutions are relatively new in our system ${ }^{13}$. There emerges a question on whether one may expect that thanks to the implementation of these regulations in Poland there will be achieved substantial fiscal effects similarly to other countries which are more developed than Poland. Based on the available statistical input it is possible to draw careful conclusions concerning the scale of benefits for fiscal authorities and the scale of burdens for the taxpayer that result from the manner of CFC taxation. The available information is rather general, while the numeric description of the taxpayers operating at the international scale does not consider important payments made by the entity paying out at the level of costs. In order to minimise tax burdens, taxpayers may use such forms of income transfer that are adjusted to their tax situation. Therefore, it is impossible to analyse tax benefits for

13 In the USA proper regulations were introduced after earlier attempts in 1962 [The Deferral, 2000, pp. 8-12]. 
fiscal authorities resulting from the existence of CFC regulations in separation from other mechanisms in the income $\operatorname{tax}^{14}$.

There are two possible conclusions concerning CFCs that are of general type. Firstly, the benefits from the earlier burden connected with the corporate income tax are not large, if there are considered only the effects of the lack of tax deferral and the value of money in time (calculations in table 1). Secondly, the relationship between direct investments of Polish residents abroad (the juxtaposition in chart 1) and foreign investments in Poland shows that the incomes of Polish residents abroad are not the most efficient source of obtaining fiscal incomes. However, they may prove to be higher when it is assumed that the incomes of Polish associated (stockholders) of CFCs, but then they would never be transferred to the country of the headquarters (residence), i.e. the incomes and taxes levied on them would be irretrievably lost. A great deal depends on tax factors as well as on the holistic way that taxpayers consider the country of residence.

From the point of view of conducting real business activity, making investments abroad may result from the factors present in the financial decisions of companies, among others, from the high cost of the external sources of financing within a country which is low abroad. Additionally, it may be caused by higher profitability of the activity run abroad that does not result from lower taxation.

Along with the analysis of these regulations there emerges the question of more general type (also interdisciplinary), e.g. what boundary conditions would be sufficient (not only tax restrictions) to counteract capital transfer from the country [Taxing..., 2000]. Additionally, there arises the problem concerning the limits of using the accrual principle in income taxes.

\section{References}

Act, 1992, Ustawa z dnia 15 lutego 1992 r. o podatku dochodowym od osób prawnych, Dz. U. 1992, nr 21, poz. 86 z późn. zm.

Bizer D.S., 1992, Capital Gains Taxation, [in:] The New Palgrave Dictionary of Money and Finance, Newman P. Milgate M., Eatwell J., (eds.), t.1, Macmillan, London.

Dmowski A., 2019, Skutki implementacji dyrektywy ATAD do polskiego systemu prawnego, „Doradztwo Podatkowe - Biuletyn Instytutu Studiów Podatkowych”, nr 8, s. 15-21, DOI: $10.5604 / 01.3001 .0013 .3751$.

Foreign Direct Investment - Rates of Return, 2019, Eurostat- Statistics explained, 2019, https://ec.europa.eu/eurostat/statistics-explained/index.php/Foreign_direct_ investment_-_rates_of_return [date of entry: 30.01.2020].

Foreign Direct Investment in Figures, 2017, OECD, http://www.oecd.org/corporate/ FDI-in-Figures-April-2017.pdf [date of entry: 20.12.2020].

Garfunkel N., 2010, Are all CFC-regimes the Same? The impact of the Attribution Method, “Tax Notes International", vol. 59(1), pp. 53-74.

${ }^{14}$ The regulations on CFC and transfer prices may double in particular situations. 
Kuźniacki B., 2017, Opodatkowanie zagranicznych spótek kontrolowanych, Wolters Kluwer Polska, Warszawa.

Majdowski F., 2017, Regulacje CFC w świetle pozostatych rekomendacji OECD z. projektu BEPS - stosunek żbieżności, wykluczenia oraz paralelizmu, Kwartalnik Prawa Podatkowego, $\mathrm{nr} 1$.

Polskie inwestycje bespośrednie za granica za lata 2012-2018, NBP, https://www.nbp.pl/ home.aspx?f=/publikacje/pib/pib.html [date of entry: 15.01.2020].

Rust A., 2008, CFC legislation and the EU tax law, "Intertax", vol. 36(11), pp. 492-501.

Taxing Capital Income in the European Union, 2000, Cnossen S. (ed.), Oxford University Press, Oxford.

The Deferral of Income Earned Through U.S. Controlled Foreign Corporations: A Policy Study, 2000, Department of Treasury.

Uchman J., 2002, Podatkowe uwarunkowania polityki dywidend spótek kapitałowych, „Prace Naukowe Akademii Ekonomicznej we Wrocławiu. Seria: Monografie i Opracowania", nr 943.

Zagraniczne inwestycje bespośrednie w Polsce i polskie inwestycje bespośrednie za granica, 2019, NBP, Warszawa, https://www.nbp.pl/home.aspx?f=/publikacje/pib/pib.html [date of entry: 10.01.2020].

Zagraniczne inwestycje bespośrednie w Polsce w 2012-2018, NBP, Warszawa, http://www. nbp.pl/home.aspx?f=/publikacje/zib/zib.html [date of entry: 10.01.2020]. 